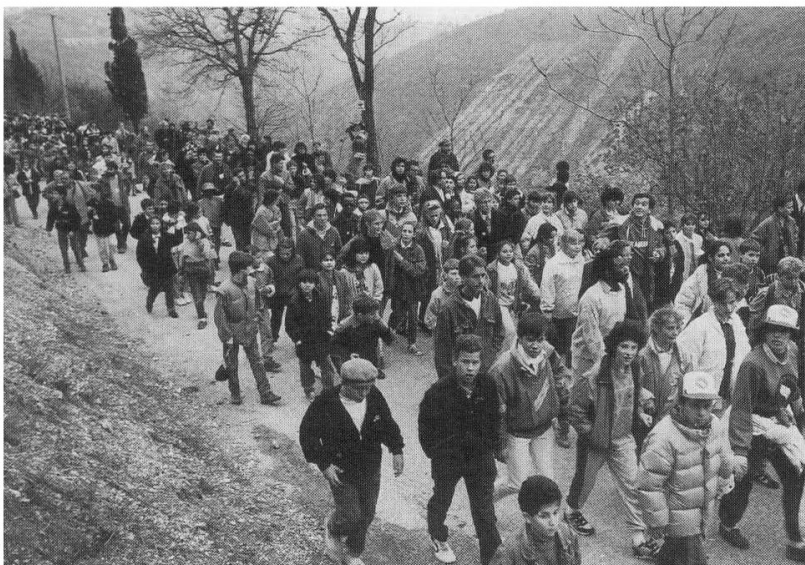

FIG. 3. A crowd of the children of the Festival walking towards Mount Subasio near Assisi to plant the International Children's Peace Grove of Indigenous Trees. Photo: Donald J. Cohen.

cational and Psychological Interactions, Department of Education and Psychological Research, Malmö School of Education, University of Lund, Sweden, 1982).

These ideals of the Festival reached a wider audience than we had hoped for: requests for participation arrived at our Headquarters (in Assisi and in Lausanne) in unexpected quantity, and with a speed that at some points threatened to overwhelm our organizational capacities. The need was in the air: from then on, environmental education could never be the same for us again.

\section{Encouraging Outcome}

When children, from all corners of the world, gathered together in the 'Cittadella' (the complex that hosted the Festival), and in the open fields and in the woods of Mount Subasio, a direct, simple, spontaneous relationship developed between them. This was not just an added bonus to the Festival's already crammed agenda, but rather the discovery of the "true' meaning of the Festival, that unfolded as a revelation and charged the atmosphere of the event with a wonderful harmony. It was the brotherhood and sisterhood of the children of the world in the name of their love for Nature, the realization that they now belonged to a world-wide movement-I hesitate to call it elite-and that the Festival was only the beginning of something that will go on and on, replicating itself through other festivals elsewhere, and through other projects, better awareness, and more knowledge.

We are now in possession of a great number of interesting projects, posters, letters, videos, poems, films, etc., by children, that constitute the beginning of a set of archives of children's expressive work on, and visions of, the future of The Environment. Furthermore, there are plans afoot to hold future festivals in other parts of the world, in accordance with the desires expressed by children and adults alike. Thus the Future has begun to be moulded by the hands of children in whom we can place our hopes.

Maria Louisa COHEN, President
Assisi Nature Council
3 Avenue de Jaman
1005 Lausanne
Switzerland.

Maria Louisa Cohen, President

Switzerland.

\title{
International Cooperation on World Conservation Information Centre: Joint Announcement by UNEP, IUCN, and WWF
}

The International Union for Conservation of Nature and Natural Resources (IUCN), the United Nations Environment Programme (UNEP), and WWF (World Wide Fund for Nature), recently signed a Memorandum of Understanding pledging their support to the IUCN Conservation Monitoring Centre. Signing on behalf of the three organizations were Dr Martin W. Holdgate, IUCN's DirectorGeneral, Dr Mostafa K. Tolba, UNEP's Executive Director, and $\mathrm{Mr}$ Charles de Haes, WWF's Director-General. Each of the three partners has pledged $£ 200,000$ a year towards establishing the Centre as a focal point for documentation and distribution of information on the state of the planet's threatened species, habitats, and living resources.

To be renamed the World Conservation Monitoring Centre (WCMC), the Centre will aim for a global overview of conservation data while at the same time making data available for those carrying out conservation and natural resources assessments at regional and national levels. WCMC will also develop a network of national databases as a means of supporting conservation action at the local level in the less-developed countries. 'It will no longer be good enough for officials to make bad decisions and claim they didn't have enough information,' said Dr Robin Pellew, Director of WCMC.

\section{Currently Based on Cambridge \& Kew but with Global Coverage}

Based at the University of Cambridge and the Royal Botanic Gardens in Kew, England, WCMC will build up comprehensive files on the 500 sites in the world that are best-known for their biological riches. It will also keep records of the thousands of threatened species of plants and animals around the world, of a global network of over 12,000 national parks and protected areas, of the state of the Earth's wildlife habitats of particular conservation concern (such as tropical forests, wetlands, and coral reefs), and of the trade in wild plants and animals and their products throughout the world.

WCMC's database will also link into other existing international conservation information systems, including those held by its three founders (see above), plus the World Bank, UNESCO, the United Nations Food and Agriculture Organization, the US Nature Conservancy, Conservation International, the International Council for Bird Preservation, the World Resources Institute, and the International Council of Scientific Unions, altogether making it probably the largest conservation database in the world

\section{Inheritance of IUCN Conservation Monitoring Centre}

To start with, WCMC will inherit the information gathered by IUCN over the last decade and held by the existing Conservation Monitoring Centre. This information includes the Red Data Books which list threatened species world-wide, the Directories of Protected Areas, and the data used to produce the United Nations' List of National Parks and to monitor countries' adherence to the Convention on International Trade in Endangered Species (CITES).

All three organizations welcomed the cooperation: "The modernization and expansion of WCMC will help the three 
partners to serve world conservation in a stronger and better way,' said Dr Holdgate.

Dr Tolba said that WCMC will enable its founders and other users to give governments, international organizations, and aid agencies, environmentally sound advice for use in their development planning, saying 'I am confident that WCMC will be a major instrument in planning for sustainable development world-wide.'

Mr de Haes said that, while WCMC can provide upto-date information to help plan WWF's world-wide conservation programme which concentrates on forests, wetlands, and species diversity, it will also ensure that such information is available to the public, so that actions by other conservation organizations, businessmen, governments, and other decision-makers, can be guided by solid factual information on the state of species around the world. 'WCMC does not deal with dull statistics but with key information about plants, fish, animals, forests, etc., whose well-being is crucial to humanity's future.'

\section{Existing Staff Being Maintained}

The former Conservation Monitoring Centre's staff of 40 , who will continue to be employees of IUCN, under new contracts signed with IUCN, will be seconded to WCMC. No decision, however, has yet been made on whether the Centre will remain permanently in England. This will depend on the judgement of its Board, said Dr Holdgate: "Cambridge, with its scientific tradition, is a good location. The Centre is now housed in temporary buildings whose lease runs out in 1989. If England wants to keep this unique world facility, new premises need to be found quickly. The prestige associated with such a world leader ought, one would expect, to attract a sponsor who would provide the modest buildings and facilities [which] we need.

Drake McHugh, Media Coordinator World Conservation Centre Avenue du Mont-Blanc CH-1196 Gland, Switzerland.

\section{The First IGBP Scientific Steering Committee on Global Changes of the Past}

The condition of the global environment of the past can be observed in ice-cores and tree-rings, and in ocean and lake sediments, as well as in terrestrial deposits, and pollen records. Now a new urge to study global changes of the past has been stimulated by compelling new evidence of linkages among the life processes and the physical and chemical conditions of the Earth's system. These and other insights into the past can be used to interpret observed trends in contemporary data in the broader context of past changes, to evaluate Earth-system models, and to hypothesize and investigate other interconnections. Breakthroughs in this area, exemplified by the evidence contained in ancient polar ice for systematic glacial-interglacial changes in the atmospheric abundance of trace gases such as carbon dioide and methane, have led to new conceptual views of the linkages among biogeochemical processes and the physical aspects of climate. These and related findings have served to focus attention not only on the effect of climate change on life processes, but, of even greater importance, the potential of those processes reciprocally to affect world climate.

In studying global change, the International GeosphereBiosphere Programme (IGBP) will depend on these invaluable records in order to understand better the causes and effects of contemporary changes. This will require careful assessment of the state-of-the-art and present limitations of various techniques, the development of new technologies, and improvements in the analysis of these data in order to facilitate more refined interpretation of past records. Integration and intercomparisons of the different records of the past will be an important aspect of this activity of the IGBP.

Opportunities in this area have been highlighted in the deliberations and reports of the Special Committee for the IGBP since its inception, affirming that the study of past geosphere-biosphere linkages* is clearly an important

* Whereas biologists can now use with impunity the title of 'International Geosphere-Biosphere Programme' on the understanding that only a 'trait d'union' (hyphen) is employed in it between Geosphere and Biosphere - which is now our regular practice in this Journal when referring to this important Programme-such mention as a 'geosphere-biosphere linkage' suggests some continuation of the alternative use of Biosphere as the totality or 'network' of living matter, which to us does not make scientific (or at least not biological) sense.-Ed. component of a study of Global Change. However, the collective effort to study aspects of past change relevant to the themes of the IGBP have, to date, unfortunately been without the broad transdisciplinary focus, as well as the international support, that are both essential for full exploitation of these opportunities.

Thus the Special Committee for the IGBP decided, at its meeting in Stockholm (October 1988), $\dagger$ following the first meeting of the IGBP Scientific Advisory Council, to give particular emphasis to research into records of past global change by charging the first of the Programme's Scientific Steering Committees with project development in this area. This project will encompass the past 150,000 years in order to include a full glacial-interglacial cycle. Particular studies will focus in greater detail on changes which have occurred during the Holocene (10,000 years B.P.), and especially during the past 1,000 years, when the human perturbation to the Earth's system began to take on global proportions. Terms of reference for this new committee will include:

(1) Assessing the possible contributions of planned or existing national and international efforts, including those of, for instance, the International Union for Quaternary Research (INQUA), as they pertain to the underlying themes and objectives of the IGBP;

(2) Developing, within one year of appointment, plans for an initial multi-techniques core IGBP project for coordinated field activities focused on the IGBP themes and objectives; and

(3) Initiating, within two years of appointment, pilot segments of this project.

Chairing this first IGBP Scientific Steering Committee is Professor Hans Oeschger, of the Department of Physics, University of Berne, Sidlerstrasse 5, Berne 3012, Switzerland. Further information can also be obtained from the IGBP Secretariat, c/o The Royal Swedish Academy of Sciences, Box 50005, S-104 05 Stockholm, Sweden: Tel. (+46-8) 1664 48; telefax (46-8) 166405 ; telex 17509 IGBP S.

$\dagger$ See also the account on pp. 355-6 of this issue. by Dr F.W.G Baker, Executive Secretary of the parent body, ICSU. - Ed. 